\title{
Internationaler, collectiever, genderdiverser
}

\author{
Dirk Geeraerts
}

NT 25 (2-3): 411-412

DOI: 10.5117/NEDTAA2020.2-3.023.GEER

\begin{abstract}
More international, collective, gender diverse

This contribution sheds light on three tendencies in the history of the journal Dutch Linguistics: the increase of Belgian authors, of female authors and of co-authors.
\end{abstract}

Keywords: Dutch linguistics, sociology of authorship

Over een tijdspanne van 25 jaar bekeken lijkt het identificeren van trends en tendensen me interessanter dan het aanwijzen van afzonderlijke hoogtepunten. Maar als je naar zulke ontwikkelingslijnen kijkt, dan zou de blik niet uitsluitend inhoudelijk mogen zijn. Natuurlijk is het interessant te weten welke taalkundige thema's en theorieën in de loop van de tijd op de voorgrond treden dan wel naar het achterplan verdwijnen, maar het is ook wel belangwekkend of de, laten we zeggen, sociologie van de auteurs aan verandering onderhevig is. Op basis van een weliswaar ruwe telling kan ik drie observaties doen. Ten eerste, als ik de levensloop van Nederlandse Taalkunde in vier periodes van zes jaar indeel (het bij de telling beschikbare stukje van 2019 wordt bij de laatste periode gevoegd), dan zie ik een toename van het aantal Belgische auteurs van ongeveer $14 \%$ naar $17 \%$ naar $25 \%$ en ten slotte $31 \%$. (Ik spreek van 'Belgische' auteurs met inbegrip van de onderzoekers uit Franstalig België. 'Belgisch' is daarbij geïnterpreteerd als een herkomstbenaming: het gaat dus niet om mensen werkzaam aan een Belgische universiteit, maar om auteurs met de Belgische nationaliteit, voor zover ik die meen te kennen). De neerlandistiek in Nederlandse Taalkunde heeft m.a.w. z'n basis verbreed - maar Suriname en de extramurale neerlandistiek zijn 
wel nog steeds slechts schaars vertegenwoordigd. Ten tweede, het aantal papers met meervoudig auteurschap stijgt van $21 \%$ in de eerste periode naar $28 \%$ in de tweede. Daarna schommelt het: eerst $25 \%$, dan $27 \%$. Het gemiddelde aantal auteurs per paper weerspiegelt deze ontwikkeling met een geleidelijke stijging van 1.25 over 1.33 en 1.38 tot 1.48 . Hier is m.i. sprake van een internationale tendens: de organisatiecultuur in het taalkundige onderzoek schuift op in de richting van het coöperatieve model dat al langer in de psychologie bestaat (en andere wetenschappen, maar de situatie in de psychologie zal de taalkundigen het meest vertrouwd zijn). Ten derde vergroot het aantal vrouwelijke auteurs, van $24.8 \%$ over $29.8 \%$ en $26.6 \%$ naar $34.6 \%$. Dat is een positieve trend, maar er is nog wel wat weg af te leggen: de gendervertekening in de academische wereld is ook in de neerlandistiek nog niet weggewerkt. Samengevat, niet slechts wat in Nederlandse Taalkunde onderzocht wordt, maar ook wie het onderzoek doet, verandert: het auteurschap wordt geleidelijk aan internationaler, collectiever, genderdiverser - en dat zijn stuk voor stuk positieve ontwikkelingen.

\section{Over de auteur}

Dirk Geeraerts, KULeuven

E-mail: dirk.geeraerts@kuleuven.be 